\title{
Epidemiological Investigations Shed Light on the Ecological Role of the Endophyte Phomopsis quercina in Mediterranean Oak Forests
}

\author{
Salvatore Moricca, Gloria Innocenti and Alessandro Ragazzi
}

\begin{abstract}
Findings of a study extending over a number of years on some key aspects of the biology and ecology of Phomopsis quercina in Mediterranean oak forests are reported. The main biometric parameters and physiological requirements of this significant endophytic fungus were determined in the laboratory. The microorganism was also studied in the field to explore its lifestyle in natural oak stands. The isolation frequencies of the fungus in various oak species were also related to the vitality of the trees (healthy or declining) and this showed that the fungus is involved in the widespread phenomenon of oak decline. In planta studies have proved the pathogenic activity of $P$. quercina in oak, and have found that it remains latent for a long time in the inner wood of oaks, but may turn into an aggressive and harmful coloniser of the tree if this is weakened by some stress factors. An important part of the study concerns an examination of the antagonism that some other endophytes, which colonise the same oak tissues and organs as $P$. quercina, display against this fungus. The increasing presence and abundance of $P$. quercina in declining (and especially drought-stressed) oaks suggests that climate change is having a significant role in destabilising the precarious balance between the host tree and the fungus, to the benefit of the latter. Lastly, some practical suggestions are offered on ways to counter the epidemic spread of this latent pathogen.
\end{abstract}

\section{Abbreviations \\ IF Isolation frequency \\ DI Disease index \\ PDA Potato-dextrose-agar}

\footnotetext{
S. Moricca $(\square) \cdot$ A. Ragazzi

Plant Pathology and Entomology Division, Department of Agrifood Production and Environmental Sciences, University of Florence, Piazzale delle Cascine 28, 50144 Florence, Italy

e-mail: salvatore.moricca@unifi.it

G. Innocenti

Department of Agricultural Sciences, University of Bologna,

Viale G. Fanin 46, Bologna, Italy
} 


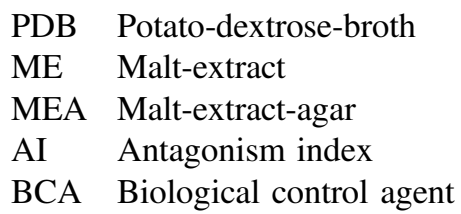

\section{Introduction}

The genus Phomopsis (Sacc.) Bubàk comprises a number of anamorphic filamentous fungi that reproduce asexually. The taxonomic affiliation and placement of the genus has been defined on the basis of morphological and ecological traits such as culture characteristics, macro- and micro-morphology (e.g. the type of stromatic structures produced by individual species, the formation of $\alpha$ and $\beta$ conidia, the size of conidia) and the host range (Brayford 1990; Rossman et al. 2007). Some of these characteristics vary within species, since they are much affected by environmental factors (Kulik 1984; Mostert et al. 2001). The Phomopsis genus, with its teleomorph in the genus Diaporthe, belongs to the Order Diaporthales, which has been included as a distinct order in the class of Sordariomycetes and, particularly on the basis of multi-gene phylogenetic analysis, in the subclass Sordariomycetidae (see Box 1) (Zhang and Blackwell 2001; Zhang et al. 2006; Udayanga et al. 2012; Santos et al. 2017).

According to Kirk et al. (2001), the ascomycete order Diaporthales comprises 94 genera. Some of the members of this Order, namely the holomorphs Apiognomonia/Discula and Diaporthe/Phomopsis are commonly found as endophytes in various trees (Rossman et al. 2007). The anamorphs deriving from the teleomorphs within this order include some very large genera, such as Cytospora (>100 species) and Phomopsis (>100 species). The genus Phomopsis comprises a great number of cosmopolitan species, which are mostly pathogenic, especially those in the Diaporthe/Phomopsis complex, causing cankers, rots, and necroses (these last alterations mostly in the woody organs) on a wide range of trees, shrubs and herbaceous plants (Rossman et al. 2007; Mueller et al. 2015). The correct identification of these taxa is vital to understand their epidemiology and their ecological role in the various agroforestry systems, to find out what has already been discovered about them, and also clearly to devise more effective means of control. The difficulty in correctly identifying these species on the basis of morphological criteria alone (deriving in part from their frequent pleomorphism) has led to other types of traits, such as physiological and molecular characters, being also used to identify them. Nowadays, approaches employed to support and extend more classical taxonomic relationships rely on biochemistry, molecular phylogenesis, 
as well as analyses of metabolite production, physiological and virulence/ pathogenicity traits, antagonistic activity and mating type (Udayanga et al. 2011).

Some species in the genus Phomopsis, basically all those that are pathogenic, produce a range of secondary phytotoxic metabolites, some of which are host-specific and important in the host-pathogen interaction as well as in symptom expression (Svabova and Lebeda 2005; Amusa 2006; Girish et al. 2009). Many species also produce other phytotoxins, as well as metabolites that protect the host-plant (Vicart et al. 1994; Horn et al. 1996; Shankar et al. 1999; Chepkirui and Stadler 2017).

The great adaptability of members of the genus Phomopsis to different areas and microclimates has favoured their expansion to agroecosystems of all continents, where they colonise a wide range of hosts (Udayanga et al. 2011).

\section{Phomopsis Quercina}

Of the numerous species in the genus Phomopsis (976 according to the Index Fungorum), Phomopsis quercina (Sacc.) Höhn ex Died. has claimed the attention of researchers because it is often found on oaks suffering from oak decline syndrome. This syndrome is a complex and widespread phenomenon in many European countries, affecting a number of oak species (Ragazzi et al. 1995; Führer 1998; Oszako and Delatour 2000; Ragazzi et al. 2000, 2004; Anselmi et al. 2004; Woo 2009; Keča et al. 2016).

In Italy, Phomopsis quercina occurs on various species of declining oak: Quercus cerris L., Quercus coccifera L., Quercus frainetto Ten., Quercus ithaburensis subsp. macrolepis (Kotschy) Hedge \& Yalt., Quercus pubescens Willd., Quercus robur L., and Quercus suber L. It is interesting to note that the frequency with which $P$. quercina is isolated from a tree is often in inverse proportion to that of other endophytic fungi that occur on the same tree organs, and that are known in the literature for their antagonism towards plant-pathogenic fungi. These other, possibly antagonistic fungi are Acremonium murorum (Corda) W. Gams, Cladosporium cladosporioides (Fresen.) G.A. de Vries, Cladosporium tenuissimum Cooke, Epicoccum nigrum Link, Gliocladium roseum Bainier, Gliocladium sp., Ramichloridium apiculatum (J.H. Mill., Giddens \& A.A. Foster) de Hoog, Trichoderma harzianum Rifai, Trichoderma viride Pers., and Ulocladium consortiale (Thüm.) E.G. Simmons. These fungi have been tested for their antagonism to P. quercina (Ragazzi et al. 2001, 2002, 2003, 2004; Vizzuso et al. 2007).

\section{Box 1. Taxonomy of Phomopsis quercina}

- Current Name: Phomopsis quercina (Sacc.) Höhn. ex Died.

- Basionym: Phoma quercina Sacc.

- Teleomorph: Diaporthe Nitschke 
- Synonymy:

Cyclophomopsis quercina (Sacc.) Höhn.

Phoma quercella Sacc. \& Roum.

Phomopsis quercella (Sacc. \& Roum.) Died.

Classification: Diaporthaceae, Diaporthales, Sordariomycetidae, Sordariomycetes, Pezizomycotina, Ascomycota, Fungi

\subsection{Life-History Traits}

In Italy, $P$. quercina was first isolated in 1983 (Ragazzi et al. 1986), in the central and southern parts of the country, from the apical twigs of symptomatic oaks. In subsequent years, the fungus was reported and isolated with increasing frequency from various oak species, and now also from trees growing in northern Italy, with isolation frequencies of up to 90.9\% (Ragazzi et al. 2000, 2004; Anselmi et al. 2004).

Phomopsis quercina also lives as an endophyte in asymptomatic oaks. In mild winters it survives largely as overwintering mycelium on infected twigs, and with a proportion of its pycnidia that form in great numbers, succeeds in part to remain vital. On the resumption of growth, in spring, the conidia are liberated from the pycnidia and infect new shoots, forming an abundant mass of inoculum that is essentially disseminated by wind, though rain and insects may also play a part here (Luciano 2009). Penetration into the tree occurs either directly, through small lesions that form naturally on the twigs, or indirectly, through the agency of a vector. The optimal temperature at which the fungus is most active is between 18 and $22{ }^{\circ} \mathrm{C}$, but it remains active even at $26-28{ }^{\circ} \mathrm{C}$. Above this, its activity slows down and it has difficulty in secreting enzymes needed for effective penetration. For the optimal spread of the fungus, these temperatures must be combined with a relative humidity of 50-60\%. In these conditions, the pathogen will infect not only young, 10-15-year-old trees, but also trees aged 30 years or older. However, infection of 2-3-year-old seedlings is rare.

\subsection{Symptoms}

The cankers produced by the fungus (on the oak species listed above) are elongated and spindle-shaped, with a length of 5-8 cm, which often however is long enough to cover almost entirely the twig, which withers as a result. The end-points of the cankers are rounded and the margins are fairly regular. In or around these cankers the pycnidia are differentiated. When the bark above a canker is removed, the 
underlying wood is considerably darker than the surrounding healthy wood. In asymptomatic trees, $P$. quercina can survive indefinitely without producing symptoms; on these trees it thus acts as a neutral organism, but only for as long as the tree is not subjected to physiological stress from adverse environmental factors. In Italy, these negative environmental factors are basically the scarcity of rainfall, and the high temperatures of the spring-summer period, which produce drought and heat stress, damaging the oak metabolism and causing an overall decline (Moricca et al. 2012). When this happens, the tree becomes weakened and is no longer able to control the fungus, which succeeds in deploying its virulence and, together with other latent pathogens occurring in the same organs or tissue niches, eventually causes the death of the tree (Ragazzi 2004; Schulze and Boyle 2005).

\subsection{Macro- and Micro-morphological Traits}

After five days of culture on potato-dextrose agar (PDA) at $24{ }^{\circ} \mathrm{C}$ in the dark, $P$. quercina mycelium is light grey in colour tending to dark, and slightly flocculent in appearance. Colony growth on PDA is rapid at that temperature, reaching a diameter of 7-8 cm after seven days. After 10-12 days of incubation the pycnidia begin to form; they are arranged in concentric circles, globose and brownish-black in colour. The conidia are of two types, type $\alpha$ and type $\beta$. Type $\alpha$ conidia are hyaline, oval and measure $8.3-12.7 \times 22.5-24.6 \mu \mathrm{m}$. Type $\beta$ conidia are spindle-shaped, curved, also hyaline, but tending to have a light-brown colour, and measuring 20.2-30.4 × 0.6-1.2 $\mu \mathrm{m}$ (Table 1).

The viability of $P$. quercina conidia obtained from 7-day-old mother colonies on PDA in 9-cm diameter Petri dishes incubated at $20{ }^{\circ} \mathrm{C}$ in the dark is shown in Table 2.

Phomopsis quercina conidia are particularly sensitive to light, and in fact conidia release peaks at night, as shown by experiments in a controlled environment chamber (Vizzuso, unpublished). A sporulation curve was constructed by placing $0.5-\mathrm{cm}$ diameter plugs of agar mycelium of $P$. quercina on 9-cm diameter Petri dishes, each containing $20 \mathrm{ml}$ of PDA, and by incubating in a controlled environment chamber

Table 1 Size of conidia (types $\alpha$ and $\beta$ ) of Phomopsis quercina

\begin{tabular}{l|l|l|l|l}
\hline Parameters & $\begin{array}{l}\text { Length }(\mu \mathrm{m}) \\
\alpha \text {-conidia }\end{array}$ & $\begin{array}{l}\text { Width }(\mu \mathrm{m}) \\
\alpha \text {-conidia }\end{array}$ & $\begin{array}{l}\text { Length }(\mu \mathrm{m}) \\
\beta \text {-conidia }\end{array}$ & $\begin{array}{l}\text { Width }(\mu \mathrm{m}) \\
\beta \text {-conidia }\end{array}$ \\
\hline $\begin{array}{l}\text { No. of } \\
\text { measurements }\end{array}$ & 100 & \multicolumn{4}{|l}{} \\
\hline Average & 23.55 & 10.5 & 25.3 & 0.9 \\
\hline Maximum & 24.6 & 12.7 & 30.4 & 1.2 \\
\hline Minimum & 22.5 & 8.3 & 20.2 & 0.6 \\
\hline Range (variation) & 2.1 & 4.4 & 10.2 & 0.6 \\
\hline $\begin{array}{l}\text { Standard } \\
\text { deviation }\end{array}$ & 1.033 & 0.751 & 1.241 & 0.843 \\
\hline
\end{tabular}


Table 2 Number of germinated Phomopsis quercina conidia and percentage of branched conidia at various temperatures (100 conidia measured at each temperature)

\begin{tabular}{l|l|l|l|l}
\hline Temperature $\left({ }^{\circ} \mathrm{C}\right)$ & 15 & 20 & 25 & 30 \\
\hline Germinated type $\alpha$ conidia & 88 & 80 & 49 & 26 \\
\hline Germinated type $\beta$ conidia & 84 & 78 & 40 & 22 \\
\hline$\beta$-conidia with branched germ tubes (\%) & 66.5 & 60.3 & 21.4 & 7.6 \\
\hline
\end{tabular}

Table 3 Number of Phomopsis quercina colonies isolated from infected twigs and that survived after 20 days of incubation at 15,20 , and $30^{\circ} \mathrm{C}$

\begin{tabular}{l|l|l|l|l|l|l|l|l|l}
\hline Sampling month & \multicolumn{3}{l}{ March } & \multicolumn{3}{l|}{ June } & \multicolumn{3}{l}{ September } \\
\hline Temperature $\left({ }^{\circ} \mathrm{C}\right)$ & 15 & 20 & 30 & 15 & 20 & 30 & 15 & 20 & 30 \\
\hline Number of surviving colonies & 80 & 71 & 25 & 72 & 66 & 20 & 70 & 60 & 18 \\
\hline Percent surviving colonies & 40 & 35.5 & 12.5 & 36 & 33 & 10 & 35 & 30 & 9 \\
\hline
\end{tabular}

with two different luminance regimes of $14 / 10$ h day/night (D/N) cycle. Five Petri dishes were incubated with the first $\mathrm{D} / \mathrm{N}$ regime and five with the second. The first regime had a D/N cycle of 25.000/5.000 lx, the second a D/N cycle of 15.000/0 lx. In both regimes, the temperature and the relative humidity (r. h.) were the same: $22 /$ $15{ }^{\circ} \mathrm{C}(\mathrm{D} / \mathrm{N})$ and $20 / 60 \%(\mathrm{D} / \mathrm{N})$. Colony growth was measured after $10 \mathrm{~h}$, then every $5 \mathrm{~h}$ until peak sporulation was reached, and thereafter for another $5+5 \mathrm{~h}$. Peak conidia release under the first, high luminance regime was reached after $40 \mathrm{~h}$ of incubation, with 55,000 conidia/ml as measured in a Bürker counting chamber. The conidial release counts for the high luminance regime were as follows: $10 \mathrm{~h}: 11,700$ conidia/ml; and then, for the counts at 15, 20, 25, 30, 35, 40, 45 and $50 \mathrm{~h}: 15,800$; 20,000; 26,500, 32,000, 47,000; 55,000 (peak release); 54,500; 54,000 respectively. The last three release numbers under this regime (for 40,45 and $50 \mathrm{~h}$ ) were almost the same. The corresponding numbers for the second, low luminance regime were: 14.600; 17,000; 24,300; 39,600; 86,000 (peak release); 58,350; 46,400; 41,700; and 38,700 conidia/ml. As regards the survival of $P$. quercina colonies at three different temperatures $\left(15,20\right.$ and $\left.30{ }^{\circ} \mathrm{C}\right)$, after 20 days of incubation, the colonies had a higher survival rate at the lower temperatures (Table 3).

Both the numbers and the percentages of surviving $P$. quercina colonies were greater at 15 and $20{ }^{\circ} \mathrm{C}$ than at $30{ }^{\circ} \mathrm{C}$. These data confirm the already known optimal temperature range for this microorganism (from 18 to $22^{\circ} \mathrm{C}$ ). The difference in colony survival between these temperatures and $30^{\circ} \mathrm{C}$ is very clear and confirms that $26-28{ }^{\circ} \mathrm{C}$ is the threshold temperature for $P$. quercina activity.

\subsection{Fungal Assemblages from the Inner Tissue of Oaks}

The dominant endophytic fungi (i.e. those with an isolation frequency greater than $15 \%$ ) associated with $P$. quercina in asymptomatic oaks in the various oak stands 
studied (in Tuscany, central Italy) are Acremonium murorum, Cylindrocarpon spp., Epicoccum nigrum, Hypoxylon mediterraneum [Biscogniauxia mediterranea (De Not.) Kuntze], Penicillium spp., and Trichoderma harzianum. Besides these, the dominant fungi associated with $P$. quercina in symptomatic oaks are Alternaria alternata, Cladosporium cladosporioides, Colpoma quercinum (Pers.) Wallr., Diplodia mutila, and Trichoderma viride. Less common taxa (found in fewer than 10 samples or with an isolation frequency of less than four isolates) are: Cephalosporium spp., Cladosporium spp., Sporotrix sp., Sphaeropsis sp., sterile mycelium, and Basidiomycetes. All the above fungi have been reported from several locations in Tuscany, on declining and declined $Q$. cerris, $Q$. pubescens and Q. robur (Ragazzi 1989; Ragazzi et al. 1990, 1995, 2000, 2004; Moricca et al. 2012). In the following paragraphs, we show results from studies on the isolation frequency, disease incidence, pathogenicity tests, and antagonism tests on $P$. quercina performed in our laboratory and field investigations.

\section{Isolation Frequency (IF)}

\subsection{Sampling and Isolation}

A forest in Tuscany containing declining oak trees and representing the ecological and silvicultural characteristics of a Tuscan oak forests was chosen for the experiment. The forest is located in Alta Val di Cecina, in a hilly area (400 m. a.s.1., $43^{\circ}$ $25^{\prime} 12^{\prime \prime} \mathrm{N}, 10^{\circ} 54^{\prime} 72^{\prime \prime} \mathrm{E}$ ), territory of Ulignano, Comune of Volterra, Province of Pisa. The average annual temperature in the forest is $12.9^{\circ} \mathrm{C}$, and the average annual rainfall $873 \mathrm{~mm}$. The incidence of oak decline and the presence of $P$. quercina in the trees of this forest were determined. The forest is a woodland with a mixed composition, with prevalence of Turkey oak (Q. cerris) and Pubescent oak $(Q$. pubescens), in association with Fraxinus ornus, Sorbus domestica, Sorbus terminalis, Pyrus pyraster and Quercus ilex and undergrowth composed of Asparagus acutifolius, Crataegus monogyna, Erica arborea, Juniperus communis, Prunus spinosa, Ruscus aculeatus, and Spartium junceum. With regard to the structure of the forest, the oak species were predominantly located in the dominant and co-dominant classes, while the other species occupied the intermediate and lower classes. The decline level of Turkey oak and Pubescent oak trees was determined on the basis of the scale of Ferretti (1994), in accordance with international rules: 1 (slight severity $=11-25 \%$ of defoliating class) or 2 (medium severity $=26-60 \%$ of defoliating class). Five asymptomatic and 5 symptomatic (decline index $=2$, presence of cankers on the apical twigs) 20-year-old $Q$. cerris and $P$. pubescens trees were sampled in two consecutive vegetative seasons, in April (bud break), June (full vegetation) and October (leaf fall). Sixteen twigs of the previous year were collected from each tree along two parallel lines placed virtually on the crown, from the four cardinal points ( 4 branches for each point), for a total of 320 twigs per 
month (160 from $Q$. cerris and 160 from $P$. pubescens, of which 80 from asymptomatic trees and 80 from symptomatic trees). In total, 1920 twigs were sampled in the two years. Twigs were sterilized by dipping for $15 \mathrm{~min}$ in $10 \%$ $\mathrm{H}_{2} \mathrm{O}_{2}$, followed by 5 rinses in sterile water, and then dried on sterile filter paper at room temperature $\left(22-24{ }^{\circ} \mathrm{C}\right)$.

Bark was removed from each sterilised twig so that only wood, phloem and cambium tissues remained, and cut into three 5-mm diameter portions. These were further fragmented into smaller segments and placed on the Petri dish to isolate fungi. The Petri dishes were $9 \mathrm{~cm}$ in diameter and each contained $20 \mathrm{ml}$ of PDA (Difco, Detroit, MI, USA) with $0.06 \mathrm{~g} / \mathrm{l}$ streptomycin. Each Petri dish was seeded with 8 twig segments, sealed with parafilm, and incubated for seven days in the dark at $20{ }^{\circ} \mathrm{C}$. At the end of the incubation period, colonies were transferred to malt extract agar (MEA) (Difco) at $2 \% \mathrm{w} / \mathrm{v}$ and stored at $4{ }^{\circ} \mathrm{C}$. The colonies were identified according to the keys of Gams (1971), Carmichael et al. (1980), Sutton (1980) and Von Arx (1987). Traditional identification was supported by molecular identification based on PCR-amplification and sequencing of the ITS1-5.8S-ITS2 region of the rDNA. The sequences were subjected to a BLAST search with a minimum threshold of $98 \%$ identity in GenBank for species identification (Sánchez Márquez et al. 2008).

The isolation frequency (IF) of each endophyte taxon was calculated using the formula:

$$
\mathrm{IF}=\mathrm{Ni} / \mathrm{Nt} \times 100
$$

where $\mathrm{Ni}$ is the number of fragments that yielded positive results, Nt the total number of seeded fragments. Data were treated with ANOVA after transformation and expressed as a percentage with ARCSIN (Tables 4, 5 and 6).

Phomopsis quercina was isolated most frequently from symptomatic trees (IF $15.1 \%$ ) but the isolation frequency was high even in asymptomatic trees $(10.1 \%)$, where it occurred in latent form (Table 4), The highest IF (13.0\%) for P. quercina in symptomatic trees was reached in the month of June (Table 5). Analysis of variance at $\mathrm{F} \leq 0.01$ detected that variations in IF between endophytes were high (Table 6). The diameter of the twigs also correlated with the IF. The IF of $D$. mutila, D. quercina and $P$. quercina was $15 \%$ higher in thin twigs $(<2 \mathrm{~cm}$ in diameter) than in thicker twigs $(2-5 \mathrm{~cm}$ in diameter) when the trees were healthy, and $25 \%$ higher when the trees were symptomatic. The IF was only $7 \%$ in thick twigs of healthy trees and $16 \%$ of symptomatic trees (data not shown).

\subsection{Disease Index and Disease Index}

The disease index was calculated in 2012 and 2014, in a mixed 20-year-old coppice consisting mostly of $Q$. cerris and partly of $Q$. pubescens, where two transects of 
Table 4 Isolation frequency of fungal species from twigs of healthy and declining Quercus cerris trees from two growing seasons at Ulignano, Province of Pisa (central Italy)

\begin{tabular}{l|l|l}
\hline \multirow{2}{*}{ Fungal species } & Current-year twigs & \multicolumn{2}{l}{} \\
\cline { 2 - 3 } & Healthy trees & Declining trees \\
\hline Acremonium murorum & 7.6 & 10.2 \\
\hline Alternaria alternate & 6.0 & 2.2 \\
\hline Cladosporium cladosporioides & 7.2 & 10.3 \\
\hline Colpoma quercinum & 8.1 & 4.0 \\
\hline Diplodia mutila & 10.9 & 13.6 \\
\hline Discula quercina & 8.7 & 10.1 \\
\hline Epicoccum nigrum & 5.2 & 1.7 \\
\hline Phoma cava & 5.6 & 3.3 \\
\hline Phomopsis quercina & 10.1 & 15.1 \\
\hline Trichoderma viride & 12.1 & 12.1 \\
\hline Da a
\end{tabular}

Data are the frequency with which each fungus was isolated from the twigs as a percentage of the total number of fungi isolated from those twigs, summing the data of the two growing seasons (Ragazzi et al. 2001, with modifications)

Table 5 Isolation frequency of fungal species from twigs of healthy and declining Quercus cerris trees at three sampling dates of two growing seasons

\begin{tabular}{l|c|c|c|c|c|c}
\hline \multirow{2}{*}{ Fungal species } & \multicolumn{3}{|l|}{ Healthy trees } & \multicolumn{3}{l}{ Declining trees } \\
\cline { 2 - 7 } & April & June & October & April & June & October \\
\hline Acremonium murorum & 8.6 & 10.6 & 11.0 & 10.9 & 11.1 & 13.6 \\
\hline Alternaria alternata & 3.4 & 2.6 & 3.4 & 3.0 & 2.3 & 3.8 \\
\hline Cladosporium cladosporioides & 8.9 & 8.8 & 6.0 & 9.6 & 11.4 & 7.9 \\
\hline Colpoma quercinum & 3.6 & 4.0 & 5.3 & 2.1 & 4.0 & 5.7 \\
\hline Diplodia mutila & 9.2 & 13.3 & 6.2 & 14.4 & 14.2 & 9.1 \\
\hline Discula quercina & 9.0 & 12.3 & 6.7 & 13.2 & 12.1 & 8.9 \\
\hline Epicoccum nigrum & 3.6 & 1.7 & 3.4 & 1.9 & 2.1 & 3.3 \\
\hline Phoma cava & 5.6 & 2.6 & 3.2 & 2.1 & 1.9 & 6.0 \\
\hline Phomopsis quercina & 8.7 & 12.1 & 5.3 & 9.2 & 13.0 & 7.9 \\
\hline Trichoderma viride & 10.5 & 8.0 & 5.2 & 6.7 & 5.2 & 5.9 \\
\hline Da
\end{tabular}

Data are the frequency with which each fungus was isolated from the twigs as a percentage of the total number of fungi isolated from those twigs, summing the data of all sampling dates (Ragazzi et al. 2001, modified)

$1200 \mathrm{~m}^{2}$ each were laid out. In 2012, out of 94 Q. cerris individuals growing along the two diagonals and the two transects, 37 trees $(39.3 \%)$ were infected, i.e. had cankers on the apical twigs. In 2014, 59 trees $(62.7 \%)$ were infected. Out of $63 Q$. pubescens individuals, 19 trees (30.1\%) were found to be infected in 2012, and in 2014, 28 trees $(44.4 \%)$ were infected.

The disease incidence is the number (which can be expressed as a percentage) of newly infected individuals over time (for example, a period of two years). It reliably 
Table 6 Analysis of variance on the isolation frequency as a function of various parameters (ARCSIN data)

\begin{tabular}{l|c|l|l|l}
\hline Variation & d.f. & Deviance & Variance & F \\
\hline Total & 14 & 1576.66 & & \\
\hline Between sampling dates & 2 & 1026.04 & 513.02 & $363.84 * *$ \\
\hline Between fungi & 9 & 546.21 & 60.69 & $43.04 * *$ \\
\hline Error & 3 & 4.41 & 1.41 & \\
\hline$* \mathrm{~F} \leq 0.01$ & \multicolumn{5}{l}{}
\end{tabular}

Table 7 Severity classes (V) and disease index (DI) of the infection caused in 2012 and 2014 by Phomopsis quercina on Quercus cerris trees

\begin{tabular}{l|l|l|l|l|l}
\hline \multirow{2}{*}{$\begin{array}{l}\text { Severity } \\
\text { class }\end{array}$} & \multirow{2}{*}{ Symptom } & \multicolumn{4}{|l}{ Number of infected twigs } \\
\cline { 3 - 6 } & & & Year 2012 & \multicolumn{2}{l}{ Year 2014 } \\
\cline { 3 - 6 } & & $\mathrm{F}$ & $\mathrm{V} \times \mathrm{F}$ & $\mathrm{F}$ & $\mathrm{V} \times \mathrm{F}$ \\
\hline 0 & No symptoms & 288 & - & 194 & - \\
\hline 1 & Twigs with incipient cankers & 146 & 146 & 180 & 180 \\
\hline 2 & Twigs with cankers $(<5 \mathrm{~cm}$ in length) & 164 & 328 & 201 & 402 \\
\hline 3 & Twigs with cankers $(>5 \mathrm{~cm}$ in length) & 193 & 579 & 266 & 798 \\
\hline 4 & Dead twigs among the above & 180 & 720 & 312 & 1240 \\
\hline Total $(\Sigma)$ & & 971 & 1773 & 1151 & 2620 \\
\hline
\end{tabular}

The test was carried out on two-year-old twigs

indicates how high is the risk that the trees of a given stand, affected by an infectious event, will become infected. The disease severity derives from the integration between the numerical or percent values obtained by calculating the disease incidence and the symptom severity assessed on sample trees according to the severity classes. The severity classes were calculated only for $Q$. cerris, by assessing in 2012 and 2014 the health state of $15+15$ infected trees, from which 20 twigs were removed (5 from each point of the compass) to total in $300+300$ twigs. Lastly, the disease index that expresses the 'average disease severity' was calculated. This index is based on the integration of disease incidence and disease severity. The disease index was calculated using the formula:

$$
\mathrm{DI}=\Sigma(V \times F) / N
$$

where $\mathrm{V}$ is the severity class; $\mathrm{F}$ the number of twigs from the various classes; and $\mathrm{N}$ the number of infected twigs out of the total number of twigs examined (Table 7).

These figures (Table 7) yield the following disease indices: $\mathrm{DI}_{2012}=1773$ / $971=1.82 ;-\mathrm{DI}_{2014}=2620 / 1151=2.27$. In 2014 the disease index $(2.27)$ was higher than in 2012 (1.82), indicating that the level of infection (average disease severity) of $Q$. cerris trees by $P$. quercina had increased. 
Table 8 Spearman's coefficient of the isolation frequency (IF) of some endophytic fungi isolated from the twigs of declining Quercus cerris and Quercus pubescens trees (Moricca and Ragazzi 2011)

\begin{tabular}{l|l|l|l}
\hline \multirow{2}{*}{ Fungus } & \multicolumn{2}{l|}{ Year } & Coefficient \\
\cline { 2 - 4 } & 2005 & 2006 & \\
\hline Apiognomonia quercina/Discula quercina & 23.4 & 23.4 & $0.700^{* * *}$ \\
\hline Biscogniauxia mediterranea & 14 & 15.6 & $0.425^{* *}$ \\
\hline Colpoma quercinum & 11.6 & 10.4 & $0.320^{*}$ \\
\hline Diplodia mutila & 10.9 & 11.7 & $0.660^{* * *}$ \\
\hline Phomopsis quercina & 11.1 & 11.7 & $0.400^{* *}$ \\
\hline
\end{tabular}

***Significant at $0.001 ; * *$ Significant at $0.01 ; *$ Significant at 0.05

The Spearman index was also calculated to have a coefficient expressing the IF of $P$. quercina in relation to other endophytes occurring on declining trees of $Q$. cerris and $Q$. pubescens that were tested, as shown in Table 8.

\section{In Planta Pathogenicity Tests}

The pathogenicity of $P$. quercina was ascertained by inoculating three-year-old $Q$. cerris, $Q$. frainetto and $Q$. pubescens seedlings with $P$. quercina inoculum (25 seedlings per species). The inoculum was obtained by homogenising seven-day-old pathogen colonies that had been incubated on PDA at $20{ }^{\circ} \mathrm{C}$ in the dark. A wound of $5 \mathrm{~mm}$ long and 2-3 mm deep was made in the seedling trunk with a sterile scalpel, and a $0.5-\mathrm{cm}$ diameter plug was placed on this wound, which was sealed with cotton wool and parafilm. Identical wounds made on three seedlings of the same oak species and inoculated with water agar served as controls. The seedlings were placed in a controlled-environment chamber (VEPHL Heraeus, model 5/1350) with the following settings: 14/10 day/night cycle; 15,000/0 lx; temperature 22/ $14{ }^{\circ} \mathrm{C}$; r.h. 40/80\%. The seedlings were inspected after seven days and every seven days thereafter until mortality, which occurred starting from day 35 after incubation. To assess the infection, the presence of cankers was recorded and their length measured (Table 9).

The pathogenicity tests suggested that $Q$. cerris was the most susceptible tree species both in terms of number of cankers and mortality, even if the differences were not so high (Table 9). Our earlier tests have shown that oak species vary considerably in their susceptibility to $P$. quercina, with $Q$. cerris being more susceptible than $Q$. pubescens and $Q$. frainetto, and susceptibility increasing with seedling age (unpublished data). A dry climate $\left(25 / 15^{\circ} \mathrm{C}\right.$; r.h. $25 / 40 \% ; 15,000 /$ $0 \mathrm{~lx}$ ) tends to make the trees more susceptible to $P$. quercina. 
Table 9 Disease severity on Quercus cerris (Q.c.), Q. frainetto (Q.f.) and Q. pubescens (Q.p.) seedlings inoculated with Phomopsis quercina

\begin{tabular}{l|l|l|l|l|l}
\hline Disease class & $\begin{array}{l}\text { Inspection (days } \\
\text { after incubation) }\end{array}$ & Symptom & \multicolumn{3}{l}{$\begin{array}{l}\text { Number of seedlings } \\
\text { with bark cankers }\end{array}$} \\
\hline \multicolumn{2}{l|}{} & & Q.c. & Q.f. & Q.p. \\
\hline 0 & 7 & No lesions & 28 & 26 & 26 \\
\hline 1 & 14 & Cankers $2 \mathrm{~cm}$ long & 5 & 3 & 2 \\
\hline 2 & 21 & Cankers 3-5 cm long & 16 & 10 & 9 \\
\hline 3 & 28 & Cankers 8-10 cm long & 25 & 17 & 14 \\
\hline 4 & 35 & Dead seedlings & 29 & 21 & 18 \\
\hline
\end{tabular}

\section{Antagonism Assays}

Studies have shown that the IF of $P$. quercina on oak varies inversely with IF of other endophyte species colonising the same tree, suggesting that these other endophytes may be acting as antagonists of P. quercina (Madrigal and Melgarejo 1995; Fiss et al. 2000; Bhuiyan et al. 2003). Our understanding of the relations between endophytes that under certain conditions will turn virulent and endophytes that may act as their antagonists in planta, is currently limited. Therefore we decided to explore the inhibitory effect of the potentially antagonistic fungi, which seemed important since these fungi were often found colonising the same tissues as $P$. quercina. Dual in vitro antagonism tests against $P$. quercina were carried out using the following fungi: Acremonium murorum, Cladosporium cladosporioides, Cladosporium tenuissimum, Epicoccum nigrum, Gliocladium roseum, Gliocladium sp., Ramichloridium apiculatum, Trichoderma harzianum, Trichoderma viride, Ulocladium consortiale. Filtrates of these fungi were also used in antagonism tests against $P$. quercina cultured in both agarised and liquid media.

\subsection{Tests on Agar Medium}

The antagonistic activity of the endophytes was investigated in dual culture experiments on two agar substrates, PDA and MEA (Sigma-Aldrich, Germany). Two types of tests were carried out: synchronous dual cultures, and asynchronous dual cultures. Antagonistic activity was evaluated using the scale of Badalyan et al. (2002), which is based on the type of hyphal interaction that occurs. The antagonism index (A.I.) was also calculated using the formula A.I. $=\Sigma(N \times V)$, where $\mathrm{N}$ is the frequency of each type of interaction, and $\mathrm{V}$ the numerical value assigned to the type of interaction itself, according to the scale shown in Table 10. 
Table 10 Types of hyphal interactions and the numerical value associated with them by the scale of Badalyan et al. (2002)

\begin{tabular}{l|l|l}
\hline \multicolumn{2}{l|}{ Type of hyphal interaction } & $\begin{array}{l}\text { Numerical value of } \\
\text { interaction }\end{array}$ \\
\hline A & Both colonies inhibited upon hyphae making contact & 1 \\
\hline B & Inhibition at a distance without mycelia coming into contact & 2 \\
\hline$C$ & One colony overgrowing the other without an initial delay & 3 \\
\hline $\mathrm{CA}_{1}$ & $\begin{array}{l}\text { One colony partly overgrowing the other after initial blockage } \\
\text { upon making contact }\end{array}$ & 3.5 \\
\hline $\mathrm{CA}_{2}$ & $\begin{array}{l}\text { One colony completely overgrowing the other after initial } \\
\text { blockage upon making contact }\end{array}$ & 4 \\
\hline $\mathrm{CB}_{1}$ & $\begin{array}{l}\text { One colony partly overgrowing the other after initial blockage } \\
\text { at a distance }\end{array}$ & 4.5 \\
\hline $\mathrm{CB}_{2}$ & $\begin{array}{l}\text { One colony completely overgrowing the other after initial } \\
\text { blockage at a distance }\end{array}$ & 5 \\
\hline
\end{tabular}

\subsubsection{Synchronous Dual Culture}

Twenty 9-cm-diameter Petri dishes were each filled with $20 \mathrm{ml}$ PDA or MEA (ten dishes per medium). When the media had solidified, two plugs of agar mycelium, 0.5-cm in diameter, obtained from 7-day-old mother colonies, were placed in each Petri dish. One plug contained P. quercina, and the other contained the possible antagonistic fungi. The plugs in each Petri dish were placed opposite to each other, $6 \mathrm{~mm}$ from the wall of the Petri dish. The Petri dishes were sealed with parafilm and incubated in the dark at $22{ }^{\circ} \mathrm{C}$. The controls consisted of Petri dishes with plugs of $P$. quercina placed opposite to water agar plugs. Colony growth was recorded at 24-h intervals for seven days. Three replicates were carried out with five repetitions per isolate and per substrate. Results were evaluated on the basis of P. quercina colony growth in $\mathrm{mm}$, measured along two perpendicular axes intersecting at the $P$. quercina plug, and taking the average of two measurements. Considering as independent variables the antagonist species, the substrate, the duration, and the interaction between these factors, the two factors 'time' and 'fungal species $x$ time' were highly significant ( $p \leq 0.01$ ), and the factor 'fungal species' was significant $(p \leq 0.025)$ (Table 11).

Phomopsis quercina growth was significantly inhibited only by $T$. viride $(4.33 \mathrm{~mm})$. In the interactions, only $T$. harzianum and $T$. viride exhibited substantial antagonism according to the scale of Badalyan et al. (2002). The type of interaction produced depended on the substrate employed. On PDA, both Trichoderma species blocked $P$. quercina growth, overgrowing its colony ( $\mathrm{C}=$ colony overgrowth without initial halt), whereas on MEA there sometimes was inhibition at a distance $\left(\mathrm{CB}_{2}\right)$, and at other times inhibition only upon making contact $\left(\mathrm{CA}_{2}\right)$. Furthermore, on the latter substrate the antagonism index was slightly higher (Table 12). 
Table 11 Analysis of variance of the antagonism of various fungi to Phomopsis quercina in synchronous dual culture

\begin{tabular}{l|c|l|l|l|l}
\hline Variable & Sum of squares & $\begin{array}{l}\text { d. } \\
\text { f. }\end{array}$ & $\begin{array}{l}\text { Mean of } \\
\text { squares }\end{array}$ & F & P \\
\hline Antagonistic fungus & 0.973 & 10 & 0.097 & 2.224 & 0.014 \\
\hline Time & 293.268 & 6 & 48.878 & 6.701 & 0.000 \\
\hline Substrate & 0.079 & 1 & 0.079 & 1.811 & 0.179 \\
\hline Fungus $\times$ time & 3.556 & 60 & 0.059 & 8.125 & 0.000 \\
\hline Fungus $\times$ substrate & 0.601 & 60 & 0.010 & 1.374 & 0.186 \\
\hline Fungus $\times$ substrate $\times$ time & 0.448 & 60 & 0.007 & 1.023 & 0.421 \\
\hline
\end{tabular}

Table 12 Type of hyphal interaction and index values of the antagonism in vitro between Phomopsis quercina and the antagonistic fungi $T$. harzianum and $T$. viride

\begin{tabular}{l|l|l}
\hline Antagonist-substrate & Type of hyphal interaction & Antagonism index \\
\hline Trichoderma viride - PDA & C & 45 \\
\hline Trichoderma harzianum - PDA & C & 42 \\
\hline Trichoderma viride - MEA & $\mathrm{C}-\mathrm{CA}_{2}-\mathrm{CB}_{2}$ & 49 \\
\hline Trichoderma harzianum - MEA & $\mathrm{C}-\mathrm{CA}_{2}$ & 46 \\
\hline
\end{tabular}

\subsubsection{Asynchronous Dual Culture}

The antagonism of fungi was then tested against $P$. quercina substantially grown (5 days) on a plate. Ten 9-cm-diameter Petri dishes each containing $20 \mathrm{ml}$ PDA, and an equal number of Petri dishes containing the same amount of MEA, each received a 0.5 -cm-diameter plug of water agar containing $P$. quercina, placed $6 \mathrm{~mm}$ from the wall of the Petri dish. The dishes were incubated as above for five days, after which they were opened under a sterile hood and a 0.5 -cm-diameter plug of one of the various antagonists was added as in the previous experiment. The asynchronous dual cultures were incubated and inspected every $24 \mathrm{~h}$ for seven days. Three replications with five repetitions per isolate and per substrate were carried out. The asynchronous dual cultures were incubated and inspected every $24 \mathrm{~h}$ for seven days. The controls consisted of a plug of water agar opposite to the 5-day-old P. quercina plug, incubated under the same conditions. Analysis of variance of the independent variables 'fungal species', 'time', 'substrate' and their interactions detected that the differences for 'fungal species', 'time' and their interaction were significant $(p \leq 0.01)$ (Table 13).

The greatest inhibition of $P$. quercina growth was observed with $T$. viride (6.3 mm). With A. murorum, C. cladosporioides, G. roseum, and R. apiculatum there were no real differences in the inhibition results between these fungi and the control. The asynchronous hyphal interactions with all the potential antagonists tested are shown in Table 14. 
Table 13 Analysis of variance of the antagonism of various fungi to Phomopsis quercina in asynchronous dual culture

\begin{tabular}{l|l|l|l|l|l}
\hline Variable & $\begin{array}{l}\text { Sum of } \\
\text { squares }\end{array}$ & $\begin{array}{l}\text { d. } \\
\text { f. }\end{array}$ & $\begin{array}{l}\text { Mean of } \\
\text { squares }\end{array}$ & F & P \\
\hline Antagonist fungus & 4.887 & 10 & 0.489 & 97.626 & 0.000 \\
\hline Time & 55.070 & 6 & 9.178 & 1.834 & 0.000 \\
\hline Substrate & 0.079 & 1 & 0.079 & 1.811 & 0.179 \\
\hline Fungus $\times$ time & 3.778 & 60 & 0.063 & 12.580 & 0.000 \\
\hline Fungus $\times$ substrate & 0.601 & 60 & 0.010 & 1.374 & 0.186 \\
\hline Fungus $\times$ substrate $\times$ time & 0.445 & 60 & 0.007 & 1.023 & 0.421 \\
\hline
\end{tabular}

Table 14 Type of hyphal interaction and index values of the antagonism in vitro between Phomopsis quercina and the antagonistic fungi on PDA and MEA substrates

\begin{tabular}{l|l|l|l|l}
\hline \multirow{2}{*}{ Antagonist } & \multicolumn{2}{l|l}{ Type of hyphal interaction } & \multicolumn{2}{l}{$\begin{array}{l}\text { Antagonism } \\
\text { index }\end{array}$} \\
\cline { 2 - 5 } & PDA & MEA & PDA & MEA \\
\hline Acremonium murorum & $\mathrm{C}$ & $\mathrm{B}-\mathrm{C}$ & 42 & 41 \\
\hline Cladosporium tenuissimum & $\mathrm{C}$ & $\mathrm{C}$ & 42 & 39 \\
\hline Cladosporium cladosporioides & $\mathrm{B}-\mathrm{CA}_{1}$ & $\mathrm{~B}-\mathrm{C}-\mathrm{CA}_{1}$ & 35.5 & 24 \\
\hline Gliocladium roseum & $\mathrm{C}$ & $\mathrm{B}-\mathrm{C}$ & 33 & 32 \\
\hline Gliocladium sp. & $\mathrm{C}-\mathrm{CA}_{1}$ & $\mathrm{C}-\mathrm{CA}_{1}$ & 44 & 37 \\
\hline Epicoccum nigrum & $\mathrm{B}$ & $\mathrm{B}-\mathrm{C}$ & 30 & 35 \\
\hline Ramichloridium apiculatum & $\mathrm{C}$ & $\mathrm{C}$ & 45 & 45 \\
\hline Trichoderma harzianum & $\mathrm{C}-\mathrm{CA}_{2}$ & $\mathrm{C}-\mathrm{CA}_{2}$ & 48 & 49 \\
\hline Trichoderma viride & $\mathrm{C}-\mathrm{CA}_{2}$ & $\mathrm{C}-\mathrm{CA}_{2}$ & 47 & 51 \\
\hline Ulocladium consortiale & $\mathrm{C}$ & $\mathrm{B}-\mathrm{C}$ & 27 & 26 \\
\hline
\end{tabular}

\subsection{Tests in Liquid Culture}

Antagonistic activity was further tested in liquid potato dextrose broth (PDB) and malt extract (ME) media (Sigma-Aldrich, Germany). For each antagonist to be tested, eight Erlenmeyer flasks were prepared, four containing $100 \mathrm{ml}$ of PDB and four of ME. The flasks were autoclaved at $120{ }^{\circ} \mathrm{C}$ for $15 \mathrm{~min}$, after which a 5 -mm-diameter plug of agar mycelium from an actively growing culture (grown for 7 days at $22{ }^{\circ} \mathrm{C}$ in the dark) of one of each antagonist was inoculated on the substrate. The flasks were closed with cotton wool, aluminium foil and parafilm, and incubated for 15 days at $22{ }^{\circ} \mathrm{C}$ in the dark. The culture was filtered under a sterile hood with 0.2- $\mu \mathrm{m}$-mesh filters (Filtropur S.0.2, Sarstedt, Germany) and $50 \mathrm{ml}$ of each culture filtrate was transferred to 100-ml Erlenmeyer flasks and inoculated with a plug of agar mycelium from 7-day-old mother colonies of $P$. quercina. $\mathrm{PDB}$ and ME cultures inoculated with water agar plugs were used as controls. The test cultures were incubated for seven days at $22{ }^{\circ} \mathrm{C}$ in the dark, after 
Table 15 Analysis of variance of the antagonism of various fungi to Phomopsis quercina in liquid culture

\begin{tabular}{l|l|l|l|l|l}
\hline Variable & Sum of squares & d.f. & Mean of squares & F & $P$ \\
\hline Fungus & 28.243 & 10 & 2.824 & 43.670 & 0.000 \\
\hline Substrate & 1.080 & 1 & 1.080 & 16.699 & 0.000 \\
\hline Fungus $\times$ substrate & 6.783 & 10 & 0.678 & 10.487 & 0.000 \\
\hline
\end{tabular}

which they were filtered through disks of sterile filter paper, oven-dried at $50{ }^{\circ} \mathrm{C}$ for $24 \mathrm{~h}$, and weighed. The produced mycelium was weighed, heated in an oven at $50^{\circ}$ $\mathrm{C}$, and weighed again, giving the fresh and dry weights of mycelium. Three replicates with five repetitions per isolate per substrate were carried out. The results were assessed based on dry weight of $P$. quercina mycelium in the culture containing the antagonist filtrate. Analysis of variance detected that the differences were always highly significant $(p \leq 0.01)$ (Table 15 ).

The antagonists varied significantly by the degree to which they inhibited $P$. quercina. The $T$. viride culture filtrate was the most inhibitory producing $11.73 \mathrm{mg}$ of $P$. quercina mycelia. The filtrates of G. roseum, T. harzianum, A. murorum and $C$. cladosporioides less so, and $R$. apiculatum the least, producing $67.3 \mathrm{mg}$ of $P$. quercina mycelia against the controls, which produced $112.36 \mathrm{mg}$ of $P$. quercina mycelia.

Antagonism between fungi manifests itself in various ways, the most important being the competition for substrate/nutrients and/or antibiosis. The test results overall indicated that $T$. viride, $T$. harzianum, A. murorum, C. cladosporioides and E. nigrum were the most effective antagonists against $P$. quercina. On the agar medium, on the other hand, $P$. quercina was most competitive over the fungi $C$. tenuissimum, $G$. roseum, Gliocladium sp., $R$. apiculatum, and $U$. consortiale in securing space and nutrients for itself. However, the possibility cannot be excluded that these fungi were unable to display their biocontrol capabilities to the full in the artificial conditions of the experiment, which may have placed them at a disadvantage.

\section{Conclusions}

The dominant endophytes of a given plant taxon are generally specialised or exclusive to that particular host and, together with the other fungi present, form distinct assemblages. Such well-defined assemblages are found in oak species as well as in other forest trees (Toti et al. 1992; Viret et al. 1994; Zhou and Hyde 2001; Otero et al. 2002; Cohen 2004; Saikkonen 2007).

Phomopsis quercina certainly occupies an important role in the communities of endophytic fungi associated with Mediterranean oaks, since it is common in several species, occurring sometimes alone and sometimes in assemblages with other endophytes. This diaporthaceous fungus, together with other fungi such as 
D. mutila and A. quercina (with its anamorph Discula quercina), is very frequently isolated from declining trees of different oak species (Philipps and Burdekin 1992; Ragazzi et al. 1997, 1999, 2000, 2004).

Latent pathogens colonising the aerial parts of plants, especially plants with large bulk such as trees, can pass the majority of their life-cycle without causing visible symptoms. Their presence becomes noticeable only when they receive particular ecological and/or physiological stimuli. The nature of the plant-endophyte interaction is such that the two partners are able to maintain a balanced and stable - even though, in some cases, antagonistic - relationship almost indefinitely without giving rise to disease. But if the defence mechanisms of the host tree become compromised or fail, the tree may no longer be able to control the endophyte, which is then released from its hitherto stable co-existence with the host and becomes virulent (Schulz et al. 1998; Schulze and Boyle 2005).

In the worst case, only a slight external change applied to the tree-endophyte relationship may suffice to alter the physiology of either partner and to tilt the subtle balance in favour of the endophyte. Such important change, occurred in the last decades in the Mediterranean region, is water stress, a consequence of prolonged and recurring summer drought, which is impairing the physiology and the metabolic processes of oak. It has been observed that many fungi that pass all or part of their life-cycle as endophytes, have the capacity to change their lifestyle upon host stress. These fungi then shift from a state of non-pathogenic quiescence to pathogenic (Moricca and Ragazzi 2008b). They begin to colonise the host, increasing their own biomass (Gonthier et al. 2006), as was shown in the present study on $P$. quercina. This may occur because of withering of the branches due to drought, no longer being able to provide sufficient water and solutes to the endophyte. The host imbalance puts the survival of the endophyte at risk. To endure, the fungus reacts by escaping the niche of inner wood and moves to the tree surface to sporulate, a natural process for those fungi which, like $P$. quercina, are horizontally transmitted. As a result, the number of fungal propagules released in the forest increases drastically. Fungal propagule pressure is particularly higher, during hot and dry summers, in oaks at an advanced state of decline/dieback. Other external factors associated with drought stress, for instance the swarming of insect vectors, can further boost the dissemination of fungal propagules (Panzavolta et al. 2017).

The overall findings of the present study, and the $P$. quercina IF data from both healthy and declining oaks in particular, indicate that climate change can cause a conflict of interest between the host and the endophyte, which is redounding to the benefit of the microbe. It is therefore clear that the climate has a profound effect on how the interrelationship between plants and their microbial associates evolves. This effect is even more pronounced in areas that are hotspots of climate change, such as the Mediterranean region.

Many fungal genera, including Phomopsis, comprise necrotrophic and hemibiotrophic species with a life cycle that includes both an asymptomatic stage and a parasitic stage in a plant. These species alternate their asymptomatic and parasitic stages with a saprophytic stage, when the fungus thrives on plant residues or on dead tissues and organs (e.g. branches and twigs) still attached to the plant (Rai and 
Agarkar 2016). Mycologists and plant-pathologists have long persisted in classifying microbial agents according to rigid schemes, in which biotrophic, necrotrophic, endophytic, pathogenic, saprophytic and epiphytic lifestyles are all distinct and non-interchangeable. This has made it difficult for them to recognise the fundamental ecological role that endophytes potentially play in natural forest ecosystems. Recently plant pathologists, however, have begun to realise that the saprophytic stage of many fungi (often considered insignificant from an epidemiological perspective) can have a crucial role in the development of plant disease. The biomass, which is produced during the saprophytic stage, directly determines the rate of fungal infection and hence the incidence and severity of a disease. A good example of this is shown by the causal agent of charcoal canker, Biscogniauxia mediterranea. This fungus, after necrotrophically colonising the bark of its host, sporulates profusely on the cankers it has produced, releasing an enormous amount of inoculum into the environment (Moricca et al. 2016). Phomopsis quercina has an altogether similar life cycle: it is also a hemibiotrophic fungus with a prevalent asymptomatic stage, which is followed by a necrotrophic stage. Such a shift in lifestyle is common to many Phomopsis species (Murali et al. 2006). After an oak tree has died, P. quercina survives on the dead wood as a saprophytic fungus, absorbing nutrients from the wood of its dead host and sporulating profusely over the tree surface (van Kan 2006).

Since $P$. quercina is so common in oak woods, and current changes in climate seem to be working in its favour, devising effective and lasting means to control this fungus will not be an easy task. The present study has shown that some endophytes, such as $T$. viride, A. murorum, $C$. cladosporioides and E. nigrum suppress $P$. quercina growth and could serve as biological control agents (BCAs). Much research is still needed, however, because the variables to be considered are manifold. For example, an unfavourable environment, which may curtail BCA establishment and survival, or the techniques employed (e.g., inappropriate times and methods of BCA application). Other variables, intrinsic to the host/parasite/ BCA tri-partite interaction itself, must also be considered (i.e. the particular reaction of the oak tree to $P$. quercina; the suppressive mechanisms of the $\mathrm{BCA}$; or the virulence of both the parasitic endophyte and the BCA); all these factors can render biological control ineffective (Moricca and Ragazzi 2008a).

Proper forest management practices can, to a certain extent, help cope with infections caused by $P$. quercina (Moricca et al. 2018). When P. quercina attacks are only slight, the amount of inoculum in the forest should be reduced by felling infected trees and lopping off branches that have started to wither, or branches with cankers on one or two-year-old twigs. It is advisable to burn all cut-off wood on site, or to remove it, taking care however to cover the debris with a tarpaulin to prevent the dispersal of spores. Reducing tree density, achieved by cutting down some infected trees, lowers the humidity in the forest and produce conditions less conducive to infection. But if the disease has reached epidemic proportions so that it can no longer be eradicated or contained, then it becomes more important to maintain the highest possible level of soil moisture so that the trees do not suffer from water stress, which predisposes them to attacks by the fungus. 
Acknowledgements Particular thanks to Dr. Celeste Vizzuso and Dr. Elena Turco, who shared with us their valuable experiences and expert knowledge on studies on endophytes of forest trees. The Authors wish also to thank Mrs. Irene Dellavalle, of the Institute for Sustainable Plant Protection of CNR, Florence, Italy, for technical assistance in the field and in the laboratory.

\section{References}

Amusa NA (2006) Microbially produced phytotoxins and plant disease management. Afr J Biotechnol 5:405-414

Anselmi N, Cellerino GP, Franceschini A et al (2004) Geographic distribution of fungal endophytes of Quercus sp. in Italy. In: Ragazzi A, Moricca S, Dellavalle I (eds) Endophytism in forest trees. Accademia Italiana di Scienze Forestali, Firenze, pp 73-89

Badalyan SM, Innocenti G, Garibyan NG (2002) Antagonistic activity of xylotrophic mushrooms against pathogenic fungi in dual culture. Phytopathol Mediterr 41:200-225

Brayford D (1990) Variation in Phomopsis isolates from Ulmus species in the British Isles and Italy. Mycol Res 94:691-697

Bhuiyan SA, Ryley MJ, Galea VJ et al (2003) Evaluation of potential biocontrol agents against Claviceps africana in vitro and in vivo. Plant Pathol 52:60-67

Carmichael JW, Kendrick WB, Conners IL et al (1980) Genera of hyphomycetes. The University of Alberta Press, Alberta 386 pp

Chepkirui C, Stadler M (2017) The genus Diaporthe: a rich source of diverse and bioactive metabolites. Mycol Prog 16:477-494

Cohen SD (2004) Endophytic-host selectivity of Discula umbrinella on Quercus alba and Quercus rubra characterized by infection, pathogenicity and mycelial compatibility. Eur J Plant Pathol 110:713-721

Ferretti M (1994) Mediterranean forest trees. A guide for crown assessment. CEC UN/ECE, Brussels, p 15

Fiss M, Kucheryava N, Schonherr J et al (2000) Isolation and characterization of epiphytic fungi from the phyllosphere of apple as potential biocontrol agents against apple scab (Venturia inequalis). J P1 Dis Protect 107:1-11

Führer E (1998) Oak decline in Central Europe: a synopsis of hypotheses. In ML McManus and AM Liebhold (eds) Proceedings: population dynamics, impacts and integrated management of forest defoliating insects. USDA Forest Service General Technical Report NE-247, pp 7-24

Gams W (1971) Cephalosporium-artige Schimmelpilze (hyphomycetes). Gustav Fischer-Verlag, Stuttgart, p 262

Girish K, Shankara BS, Raveesha KA (2009) Crude toxin extract from culture filtrate of Phomopsis azadirachtae infecting neem and its phytotoxicity. Int J Integr Biol 6:79-84

Gonthier P, Gennaro M, Nicolotti G (2006) Effects of water stress on the endophytic mycota of Quercus robur. Fungal Diver 21:69-80

Horn WS, Simmonds MSJ, Scwarthz RE et al (1996) Variation in production of Phomodiol and Phomopsolide B by Phomopsis spp. Mycologia 88:588-595

Keča N, Koufakis I, Dietershagen J et al (2016) European Oak decline phenomenon in relation to climatic changes. Folia For Pol Ser A For 58:170-177

Kirk PM, Cannon PF, David JC et al (eds) (2001) Ainsworth and Bisby's dictionary of the Fungi, 9th edn. CAB International, Kew

Kulik MM (1984) Symptomless infection, persistence and production of pycnidia in host and non-host plants by Phomopsis batatae, Phomopsis phaseoli and Phomopsis sojae and the taxonomic implications. Mycologia 76:274-291

Luciano P (2009) Tecniche di monitoraggio fitosanitario e utilizzo di dati georeferenziati. Atti Accad Naz It Entomol, LVII, pp 83-97 
Madrigal C, Melgarejo P (1995) Morphological effects of Epicoccum nigrum and its antibiotic flavipin on Monilinia laxa. Can J Bot 18:425-431

Moricca S, Bracalini M, Croci F et al (2018) Biotic factors affecting ecosystem services in urban and peri-urban forests in Italy: the role of introduced and impending pathogens and pests. Forests 9(2):65. https://doi.org/10.3390/f9020065

Moricca S, Ginetti B, Ragazzi A (2012) Species and organ specificity in endophytes colonizing healthy and declining Mediterranean oaks. Phytopathol Mediterr 51:587-598

Moricca S, Ragazzi A (2008a) Biological and integrated means to control rust diseases. In: Ciancio A, Mukerji KG (eds) Integrated management of disease caused by fungi, Phytoplasma and bacteria. Springer, Heidelberg 303-332 pp

Moricca S, Ragazzi A (2008b) Fungal endophytes in Mediterranean oak forests: a lesson from Discula quercina. Phytopathology 98:380-386

Moricca S, Ragazzi A (2011) The Holomorph Apiognomonia quercina/Discula quercina as a Pathogen/Endophyte in oak. In: Pirttilä AM, Frank C (eds) Endophytes of forest trees: biology, and application. Forestry sciences, vol 80. Springer Science+Business Media, Berlin 47-66 pp

Moricca S, Linaldeddu BT, Ginetti B et al (2016) Endemic and emerging pathogens threatening cork oak trees: management options for conserving a unique forest ecosystem. Plant Dis 100:2184-2193

Mostert L, Crous PW, Kang JC et al (2001) Species of Phomopsis and a Libertella sp. occurring on grapevines with specific reference to South Africa: morphological, cultural, molecular and pathological characterization. Mycologia 93:146-167

Mueller D, Bradley C, Chilvers M et al (2015) Pod and stem blight and Phomopsis seed decay. Soybean Dis Manag CPN-1007

Murali TS, Suryanarayanan TS, Geeta R (2006) Endophytic Phomopsis species: host range and implications for diversity estimates. Can J Microbiol 52:673-680

Oszako T, Delatour C (2000) Recent advances on oak health in Europe. Forest Research Institute, Warsaw, p 281

Otero JT, Ackerman JD, Bayman P (2002) Diversity and host specificity of endophytic Rhizoctonia-like fungi from tropical orchids. Am J Bot 89:1852-1858

Panzavolta T, Panichi A, Bracalini M et al (2017) Dispersal and propagule pressure of Botryosphaeriaceae species in a declining oak stand is affected by insect vectors. Forests 8 (7):228. https://doi.org/10.3390/f8070228

Philipps DH, Burdekin DA (1992) Diseases of forest and ornamental trees. The MacMillan Press LTD, London, p 537

Ragazzi A (1989) Popolazioni fungine associate a piante deperenti di Quercus cerris. Micol Ital 18:127-132

Ragazzi A (2004) Endophytism: knowns and unknowns of an age-old phenomenon. In: Ragazzi A, Moricca S, Dellavalle I (eds) Endophytism in forest trees. Accademia Italiana di Scienze Forestali, Firenze, pp 17-32

Ragazzi A, Dellavalle-Fedi I, D’Onofrio G (1986) Osservazioni preliminari su un deperimento di Quercus robur L. e Q. frainetto Ten. In Italia. Atti delle Giornate Fitopatologiche, Riva del Garda 2:241-252

Ragazzi A, Dellavalle Fedi I, Moricca S (1990) Modello di colonizzazione di Quercus cerris da parte di Diplodia mutila e Phomopsis quercina. Phytopathol Mediterr 29:209-212

Ragazzi A, Dellavalle I, Moricca S, Capretti P, Raddi P (2000) Decline of oak species in Italy, problems and perspectives. Accademia Italiana di Scienze Forestali, Firenze, p 257

Ragazzi A, Vagniluca S, Moricca S (1995) European expansion of oak decline, involved micorganisms, and methodological approaches. Phytopathol Mediterr 34:207-226

Ragazzi A, Moricca S, Dellavalle I (1997) Vegetative compatibility and pathogenicity of Diplodia mutila isolates on oak. Eur J For Pathol 27:391-396

Ragazzi A, Moricca S, Dellavalle I (1999) Epidemiological aspects of Discula quercina on oak: inoculum density and conidia production. J Pl Dis Protect 106:501-506

Ragazzi A, Moricca S, Dellavalle I (2004) Endophytism in forest trees. Accademia Italiana di Scienze Forestali, Firenze, p 239 
Ragazzi A, Capretti P, Turco E et al (2002) Endofiti di Quercus cerris: studio comparativo in piante sane e deperenti. Micol Ital 31:66-70

Ragazzi A, Moricca S, Capretti P et al (2003) Differences in composition of endophytic mycobiota in twigs and leaves of healthy and declining Quercus species in Italy. Forest Pathol 33:31-38

Ragazzi A, Moricca S, Capretti P et al (2001) Endophytic fungi in Quercus cerris: isolation frequency in relation to phenological phase, tree health and the organ affected. Phytopathol Mediterr 40:165-171

Rai M, Agarkar G (2016) Plant-fungal interactions: what triggers the fungi to switch among lifestyles? Crit Rev Microbiol 42:428-438

Rossman AY, Farr DF, Castlebury LA (2007) A review of the phylogeny and biology of the Diaporthales. Mycoscience 48:135-144

Sánchez Márquez S, Bills GF, Zabalgogeazcoa I (2008) Diversity and structure of the fungal endophytic assemblages from two sympatric coastal grasses. Fungal Divers 33:87-100

Saikkonen K (2007) Forest structure and fungal endophytes. Fungal Biol Rev 21:67-74

Santos L, Alves A, Alves R (2017) Evaluating multi-locus phylogenies for species boundaries determination in the genus Diaporthe. Peer J 5:e3120. https://doi.org/10.7717/peerj.31205

Shankar M, Cowling WA, Sweetingham MW et al (1999) Screening for resistance to Diaporthe toxica in lupins by estimation of phomopsins and glucoseamine in individual plants. Plant Pathol 48:320-324

Schulze B, Boyle C (2005) The endophytic continuum. Mycol Res 109:661-686

Schulz B, Guske S, Dammann U et al (1998) Endophyte-host interactions. II. Defining symbiosis of the endophyte-host interaction. Symbiosis 25:213-227

Sutton BC (1980) The Coelomycetes. Fungi Imperfecti with Pycnidia, Acervuli and Stromata. CMI, Kew 696 pp

Svabova L, Lebeda A (2005) In vitro selection for improved plant resistance to toxin-producing pathogens. J Phytopathol 153:52-64

Toti L, Chapela IH, Petrini O (1992) Morphometric evidence for host-specific strain formation in Discula umbrinella (teleomorph: Apiognomonia errabunda). Mycol Res 96:420-424

Udayanga D, Liu X, Crous PW et al (2012) A multi-locus phylogenetic evaluation of Diaporthe (Phomopsis). Fungal Divers 56:157-171

Udayanga D, Liu X, Mc Kenzie EHC et al (2011) Genus Phomopsis: biology, applications, specie concepts and names of common phytopathogens. Fungal Divers 50:189-225

van Kan JAL (2006) Licensed to kill: the lifestyle of a necrotrophic plant pathogen. Trends Plant Sci 11:247-253

Vicart N, Ortholand JY, Emeric GY et al (1994) Syntesis and absolute configuration of phomozin. Tehrahedon Lett 35:3917-3918

Viret O, Toti L, Chapela IH et al (1994) The role of the extracellular sheath in recognition and attachment of conidia of Discula umbrinella (Berk. And Br.) Morelet to the host surface. New Phytol 127:123-131

Vizzuso C, Turco E, Dellavalle I et al (2007) Interazioni antagonistiche in vitro fra Phomopsis quercina e funghi endofitici di specie quercine. Micol Ital 2:30-38

Von Arx JA (1987) Plant pathogenic fungi. J. Cramer Verlag, Berlin, p 288

Woo SY (2009) Forest decline of the world: a linkage with air pollution and global warming. Afr J Biotechnol 8:7409-7414

Zhang N, Blackwell M (2001) Molecular phylogeny of dogwood anthracnose fungus (Discula destructiva) and the Diaporthales. Mycologia 93:355-365

Zhang N, Castlebury LA, Miller AN et al (2006) An overview of the systematics of the Sordariomycetes based on a four-gene phylogeny. Mycologia 98:11077-11088

Zhou DQ, Hyde KD (2001) Host-specificity, host-exclusivity and host-recurrence in saprobic fungi. Mycol Res 105:1449-1457 